\title{
Hydroxymycotrienins A and B, New Ansamycin Group Antibiotics
}

\author{
Nobuo Hosokawa, Hiroshi Naganawa, Masa Hamada and Tomio Takeuchi \\ Institute of Microbial Chemistry \\ 3-14-23 Kamiosaki, Shinagawa-ku, Tokyo 141, Japan \\ SOUICHI IKENO and MAKoto HoRI \\ Showa College of Pharmaceutical Sciences, \\ Machida City, Tokyo 194, Japan \\ (Received for publication November 21, 1995)
}

\begin{abstract}
New ansamycins designated hydroxymycotrienins A and B were isolated from culture broths of Bacillus sp. BMJ958-62F4. The two antibiotics inhibited more strongly the growth of human cervical cancer cell lines of human papilloma virus (HPV) positive than that of HPV negative cell lines. The structures, some biological and biochemical properties are reported.
\end{abstract}

There is much evidence that specific types of human papilloma virus (HPV) are responsible for $70 \%$ or more of human cervical cancers. The proteins encoded by E6 and E7 genes of the cancer-causing types of HPV inactivate respectively the protein products of $\mathrm{p} 53$ and $\mathrm{Rb}$, the major tumor-suppressor genes ${ }^{1)}$.

Inhibitors of the E6 and/or E7 gene function could be effective against the cervical cancers that express those HPV genes. An in vitro screening was initiated to find microbial products that inhibited more strongly the growth of HPV positive human cervical cancer cell lines (HeLa, CaSki, SiHa) than that of HPV negative cell lines (C33A and HT-3). The study led us to find new members of the ansamycin family antibiotics designated hydroxymycotrienins A and B (Fig. 1). We report here the production, isolation, physico-chemical properties, the structures, some biological and biochemical properties of the two substances.
Production, Isolation and Structural

Determination

Fermentation of the Antibiotic Producing Strain

A loopful of a slant culture of Bacillus sp. BMJ958-62F4 was inoculated into two 500-ml Erlenmeyer flasks each containing $110 \mathrm{ml}$ of a medium composed of $5.0 \%$ glucose, $0.4 \%$ Pepton (Nippon SEIYAKU Co. Ltd.), $0.1 \%$ yeast extract, $0.1 \%$ meat extract, $0.25 \% \mathrm{NaCl}, 1.0 \%$ soybean meal and $0.5 \%$ $\mathrm{CaCO}_{3}$. The $\mathrm{pH}$ was adjusted to 7.0 before sterilization by autoclaving.

After 2 days of fermentation at $27^{\circ} \mathrm{C}$ on a rotary shaker, about $2 \mathrm{ml}$ portions of the seed culture were transferred to 90 flasks, each containing $110 \mathrm{ml}$ of the same medium as described above. Fermentation was continued for two weeks under the same conditions as for the seed culture.

Isolation of the Antibiotics

As shown in Fig. 2, 5-liter culture broth was filtered

Fig. 1. Structure of $\mathbf{1}$ and $\mathbf{2}$.<smiles>COC(=O)C(/C=C/C=C/C=C/CC(O)C(C)C(O)/C(C)=C\CCCC1=C(O)C(=O)C=C(NC(=O)CC(C)OC)C1=O)OC</smiles><smiles></smiles> 
to separate the mycelial cake. The mycelial cake was stirred successively with 2 liters of $\mathrm{MeOH}$ and 2 liters of $66 \%$ aqueous acetone, one hour each, and filtered. The filtrates were combined and concentrated in vacuo to remove the organic solvents resulting in an aqueous solution. The condensed solution was combined with the

Fig. 2. Isolation procedure for 1 and 2.

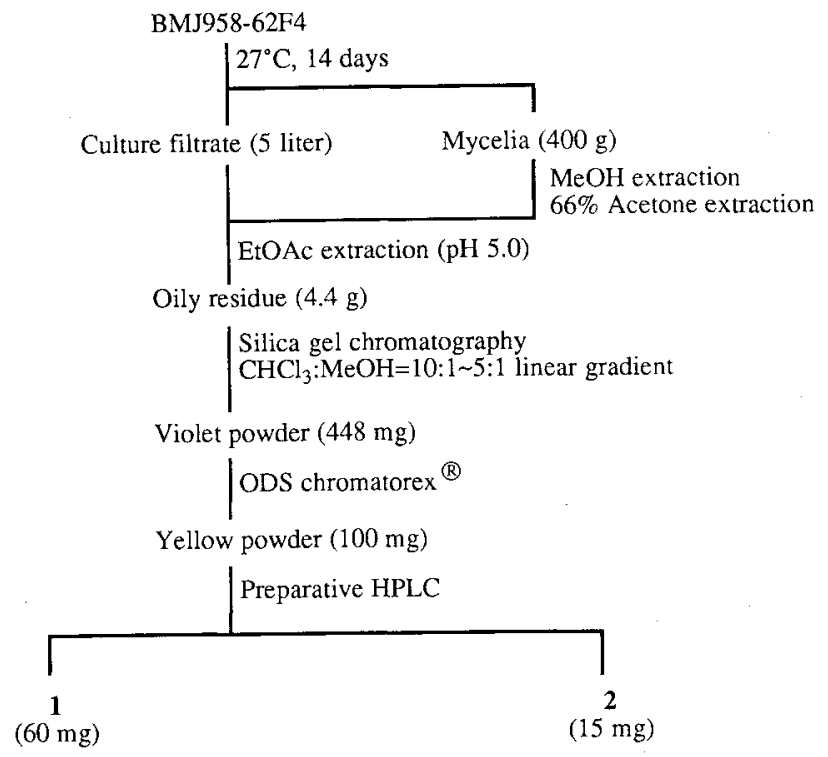

culture filtrate and the antibiotics were extracted with an equal volume of EtOAc (5 liters). The EtOAc extract was concentrated in vacuo to an oily residue $(4.4 \mathrm{~g})$, which was chromatographed on a silica gel column $(100 \mathrm{~g}, 5 \times 20 \mathrm{~cm})$ using a linear gradient elution of $\mathrm{CHCl}_{3}-\mathrm{MeOH}(10: 1 \sim 5: 1,0.5$ liters in total). Biologically active fractions (inhibitory against the growth of HeLa cells in vitro) were collected and evaporated to dryness yielding a violet powder, from which active substances were further purified by an ODS column chromatography (Chromatorex, $2 \times 30 \mathrm{~cm}$, SSC Co. Ltd., Tokyo) developed with $70 \% \mathrm{MeOH} / 12 \mathrm{~mm}$ phosphate buffer ( $\mathrm{pH} 2.89$ ), and then by a preparative HPLC (using a $\mu$-Bondasphere $C_{18}$ column, $5 \mu \mathrm{m}-100 \AA, 19 \times 150 \mathrm{~mm}$, Waters Co. Ltd.) developed with $70 \% \mathrm{MeOH} / 12 \mathrm{~mm}$ phosphate buffer $(\mathrm{pH} 2.89)$ at an elution rate of 9.9 $\mathrm{ml} / \mathrm{minute}$ at $40^{\circ} \mathrm{C}$ under monitoring at $260 \mathrm{~nm}$. Two active substances, whose purities were confirmed by HPLC and TLC, were named hydroxymycotrienins A (1) and B (2). The physico-chemical properties of $\mathbf{1}$ and 2 are shown in Table 1.

\section{Structure of 1}

The molecular formula of $\mathbf{1}$ was established as $\mathrm{C}_{36} \mathrm{H}_{48} \mathrm{~N}_{2} \mathrm{O}_{9}$ (MW 652) from HRFAB-MS and NMR

Table 1. Physico-chemical properties of $\mathbf{1}$ and 2.

\begin{tabular}{|c|c|c|}
\hline & 1 & 2 \\
\hline Appearance & Yellow powder & Brown powder \\
\hline$[\alpha]_{\mathrm{D}}^{22}(c 0.1, \mathrm{MeOH})$ & $+190^{\circ}$ & $+150^{\circ}$ \\
\hline Molecular formula & $\mathrm{C}_{36} \mathrm{H}_{48} \mathrm{~N}_{2} \mathrm{O}_{9}$ & $\mathrm{C}_{36} \mathrm{H}_{48} \mathrm{~N}_{2} \mathrm{O}_{9}$ \\
\hline FAB-MS ( $m / z$, Neg.) & $651(\mathrm{M}-\mathrm{H})^{-}$ & $651(\mathrm{M}-\mathrm{H})^{-}$ \\
\hline FAB-MS ( $m / z$, Pos.) & $675(\mathrm{M}+\mathrm{Na})^{+}$ & $675(\mathrm{M}+\mathrm{Na})^{+}$ \\
\hline \multicolumn{3}{|l|}{ HRFAB-MS ( $m / z$, Neg.) } \\
\hline Calcd. & $652.3360\left(\right.$ as $\mathrm{C}_{36} \mathrm{H}_{48} \mathrm{~N}_{2} \mathrm{O}_{9}$ ) & $652.3360\left(\right.$ as $\mathrm{C}_{36} \mathrm{H}_{48} \mathrm{~N}_{2} \mathrm{O}_{9}$ ) \\
\hline Found & $652.3373 \mathrm{M}^{-}$ & $652.3394 \mathrm{M}^{-}$ \\
\hline $\mathrm{UV}_{\mathrm{nm}} \lambda_{\max }^{\mathrm{MeOH}}(\log \varepsilon)$ & $\begin{array}{l}245(\mathrm{sh})(4.19), 250(4.46), 260(4.52) \\
272(4.57), 280(\mathrm{sh})(4.50), 315(4.06)\end{array}$ & $\begin{array}{l}245(\mathrm{sh})(4.46), 250(4.50), 260(4.55) \\
272(4.59), 280(\mathrm{sh})(4.52), 315(4.07)\end{array}$ \\
\hline $\mathrm{UV}_{\mathrm{nm}} \lambda_{\mathrm{max}}^{\mathrm{MeOH}-\mathrm{NaOH}}(\log \varepsilon)$ & $\begin{array}{l}240(\mathrm{sh})(4.40), 250(4.45), 260(4.52) \\
272(4.58), 280(\mathrm{sh})(4.51), 320(4.07)\end{array}$ & $\begin{array}{l}240(\mathrm{sh})(4.40), 250(4.48), 260(4.56) \\
272(4.60), 280(\mathrm{sh})(4.53), 320(4.08)\end{array}$ \\
\hline $\mathrm{UV}_{\mathrm{nm}} \lambda_{\max }^{\mathrm{MeOH}-\mathrm{HCl}}(\log \varepsilon)$ & $\begin{array}{l}208(4.26), 250(\mathrm{sh})(4.26), 260(4.50) \\
272(4.61), 280(4.52), 305(4.08)\end{array}$ & $\begin{array}{l}208(4.30), 250(\mathrm{sh})(4.34), 260(4.53) \\
270(4.63), 280(4.55), 305(4.15)\end{array}$ \\
\hline $\mathrm{IR} v_{\max }^{\mathrm{KBr}} \mathrm{cm}^{-1}$ & $\begin{array}{l}3350(\mathrm{NH}, \mathrm{OH}), 1210,1730 \text { (ester) } \\
1530,1660 \text { (amide), } 1000 \text { (triene) }\end{array}$ & $\begin{array}{l}3350(\mathrm{NH}, \mathrm{OH}), 1210,1730 \text { (ester) } \\
\quad 1530,1660 \text { (amide), } 1000 \text { (triene) }\end{array}$ \\
\hline \multirow[t]{3}{*}{$\mathrm{Rf}$ value on TLC } & $\begin{array}{l}\text { 1) } 0.54\left(\mathrm{CHCl}_{3}-\mathrm{MeOH}=10: 1\right. \\
\text { silica gel Art. } 5715)\end{array}$ & $\begin{array}{l}\text { 1) } 0.61\left(\mathrm{CHCl}_{3}-\mathrm{MeOH}=10: 1\right. \\
\text { silica gel Art. } 5715)\end{array}$ \\
\hline & $\begin{array}{l}\text { 2) } 0.28 \text { (Toluene }- \text { Acetone }=3: 2 \\
\text { silica gel Art. } 5715)\end{array}$ & $\begin{array}{l}\text { 2) } 0.34 \text { (Toluene }- \text { Acetone }=3: 2 \\
\text { silica gel Art. } 5715)\end{array}$ \\
\hline & $\begin{array}{l}\text { 3) } 0.72\left(\text { Toluene }-\mathrm{CHCl}_{3}-\mathrm{MeOH}=3: 7: 3\right. \\
\text { silica gel Art. } 5715)\end{array}$ & $\begin{array}{l}\text { 3) } 0.78 \text { (Toluene }-\mathrm{CHCl}_{3}-\mathrm{MeOH}=3: 7: 3 \\
\text { silica gel Art. } 5715)\end{array}$ \\
\hline Color reaction & Phosphomolybdate- $\mathrm{H}_{2} \mathrm{SO}_{4} \mathrm{FeCl}_{3}$ & Phosphomolybdate- $\mathrm{H}_{2} \mathrm{SO}_{4} \mathrm{FeCl}_{3}$ \\
\hline HPLC retention time (min)* & 5.5 & 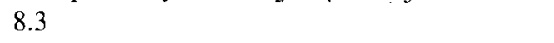 \\
\hline Solubility & $\begin{array}{ll}\text { Soluble: } & \text { DMSO, } \mathrm{CHCl}_{3}, \mathrm{MeOH} \text {, pyridine, } \\
& \mathrm{Me}_{2} \mathrm{CO}\end{array}$ & $\begin{array}{ll}\text { Soluble: } & \text { DMSO, } \mathrm{CHCl}_{3}, \mathrm{MeOH} \text {, pyridine, } \\
& \mathrm{Me}_{2} \mathrm{CO}\end{array}$ \\
\hline & Insoluble: $\quad \mathrm{H}_{2} \mathrm{O}, n$-Hexane & Insoluble: $\quad \mathrm{H}_{2} \mathrm{O}, n$-Hexane \\
\hline
\end{tabular}

* Column: $\mu$-Bondaspere $5 \mu \mathrm{C}_{18}-100 \AA$ (3.9 mm $\left.\times 150 \mathrm{~mm}\right)$. mobile phase: $70 \% \mathrm{MeOH} / 12 \mathrm{~mm}$ phosphate buffer (pH 2.89). flow rate: $1.0 \mathrm{ml} /$ minute detection: $260 \mathrm{~nm}$ temperature: $40^{\circ} \mathrm{C}$. 
Fig. 3. Structure of $\mathbf{1}$ elucidated by ${ }^{1} \mathrm{H}^{-1} \mathrm{H}$ COSY, NOE and $\mathrm{HMBC}$ experiments.

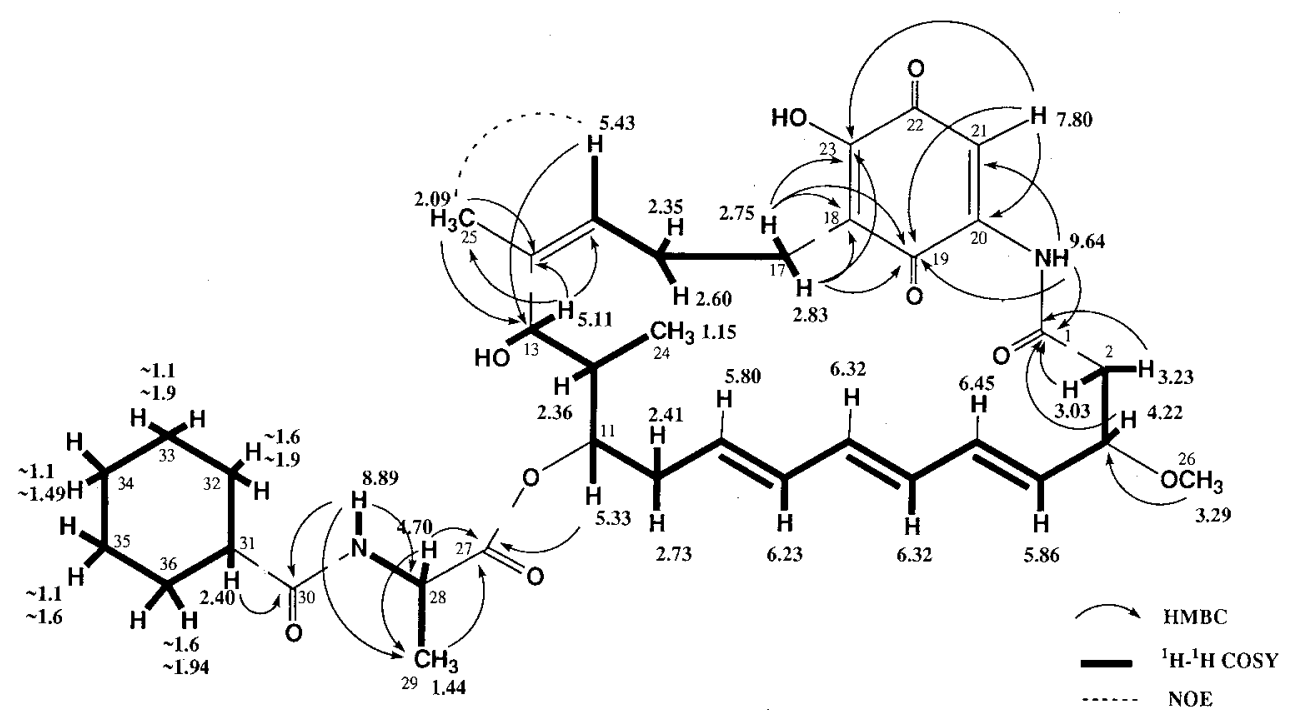

spectral data.

The UV absorption maxima in $\mathrm{MeOH}$ at $260 \mathrm{~nm}(\log \varepsilon$ 4.52), $272 \mathrm{~nm}(\log \varepsilon 4.57)$ and $280 \mathrm{~nm}(\log \varepsilon 4.50)$ indicated the presence of a triene structure in the molecule. The IR spectrum showed a strong absorption at 1000 $\mathrm{cm}^{-1}$ arising from the triene structure.

Analysis of ${ }^{1} \mathrm{H}-{ }^{1} \mathrm{H}$ COSY spectrum gave four partial structures consisting of the following fragments: from C-2 to $\mathrm{C}-13$, from $\mathrm{C}-15$ to $\mathrm{C}-17$, from $\mathrm{C}-28$ to $\mathrm{C}-29$ and from $\mathrm{C}-31$ to $\mathrm{C}-36$. The linkage between $\mathrm{C}-13$ and $\mathrm{C}-14$ was demonstrated by $\mathrm{HMBC}$ experiment, while that between $\mathrm{C}-25$ and $\mathrm{C}-15$ was shown by the observation of NOE between $25-\mathrm{H}_{3}$ and $15-\mathrm{H}$.

The HMBC spectrum of 1 revealed the structure which was the same as that of mycotrienin- $\mathrm{I}^{2,3)}$ except for the substitution of a hydroxyl group in the benzoquinone moiety as shown in Fig. 3. The difference in molecular weights between the two compounds is 16, suggesting the presence of an extra oxygen atom in 1 . The UV absorption profile which showed a bathochromic shift from $305 \mathrm{~nm}(\log \varepsilon 4.08)$ in acidic $\mathrm{MeOH}$ to $320 \mathrm{~nm}(\log \varepsilon$ 4.07) in alkaline $\mathrm{MeOH}$ solution and a positive color reaction with ferric chloride are consistent with the 'presence of the hydroxyl group in the benzoquinone chromophore. In addition, the HMBC spectrum showed that $21-\mathrm{H}\left(\delta_{\mathrm{H}} 7.80\right)$ was coupled to $\mathrm{C}-19\left(\delta_{\mathrm{C}} 182.68\right)$, $\mathrm{C}-20\left(\delta_{\mathrm{C}} 140.23\right)$ and $\mathrm{C}-23\left(\delta_{\mathrm{C}} 157.31\right)$, while $17-\mathrm{H}_{2}\left(\delta_{\mathrm{H}}\right.$ $2.75,2.83)$ were coupled to $\mathrm{C}-18\left(\delta_{\mathrm{C}} 118.48\right), \mathrm{C}-19$ and $\mathrm{C}-23$. The chemical shift of $\mathrm{C}-23\left(\delta_{\mathrm{C}} 157.31\right)$ is assignable to an aromatic carbon bearing the hydroxyl group.
No hydroxyl protons at $\mathrm{C}-13$ and $\mathrm{C}-23$ were observed in the ${ }^{1} \mathrm{H}$ NMR spectrum (pyridine- $d_{5}$ ). However, the presence of the two hydroxyl groups in $\mathbf{1}$ was confirmed by the NMR analysis of a diacetyl derivative which was obtained by a treatment of 1 with pyridine and acetic anhydride at room temperature for 3 hours. The result of NMR analysis is shown in Fig. 4. On the basis of these results, the planar structure of $\mathbf{1}$ was concluded as shown in Fig. 1.

\section{Structure of 2}

The molecular formula of $\mathbf{2}$ is the same as that of $\mathbf{1}$, $\mathrm{C}_{36} \mathrm{H}_{48} \mathrm{~N}_{2} \mathrm{O}_{9}$. The UV spectra of $\mathbf{2}$ were almost the same as those of 1 . The comparisons for ${ }^{1} \mathrm{H}$ and ${ }^{13} \mathrm{C}$ NMR data of $\mathbf{2}$ with those of $\mathbf{1}$ revealed that the structure of $\mathbf{2}$ was different from that of $\mathbf{1}$ in the ansa-ring moiety. The ${ }^{1} \mathrm{H}$ and ${ }^{13} \mathrm{C}$ NMR signals of $\mathrm{C}-11$ were observed at $\delta_{\mathrm{H}} 3.99$ and $\delta_{\mathrm{C}} 70.85$ for 2 and $\delta_{\mathrm{H}} 5.33$ and $\delta_{\mathrm{C}} 75.37$ for 1 , while those of C-13 were observed at $\delta_{\mathrm{H}} 6.47$ and $\delta_{\mathrm{C}}$ 74.37 for 2 and $\delta_{\mathrm{H}} 5.11$ and $\delta_{\mathrm{C}} 68.69$ for 1 . In the HMBC spectra of 2 , the proton signal of $13-\mathrm{H}\left(\delta_{\mathrm{H}} 6.47\right)$ was coupled to $\mathrm{C}-27\left(\delta_{\mathrm{C}} 173.31\right)$. The ${ }^{1} \mathrm{H}^{-13} \mathrm{C}$ long range cross peak indicates that $N$-(cyclohexylcarbonyl)alanine moiety is linked to $\mathrm{C}-13$.

Though the two hydroxyl protons at $\mathrm{C}-11$ and $\mathrm{C}-23$ were not observed in pyridine- $d_{5}$, their existence were confirmed by the NMR analysis of the diacetyl derivative of 2 which was obtained by the same procedure for the aceteyl derivative of $\mathbf{1}$, as shown in Fig. 4. Thus, the planar structure of 2 was established as shown in Fig. 1. 
Table 2. ${ }^{13} \mathrm{C}$ and ${ }^{1} \mathrm{H}$ NMR data of $\mathbf{1}$ and 2.

\begin{tabular}{|c|c|c|c|c|}
\hline \multirow{2}{*}{$\begin{array}{l}\text { Carbon } \\
\text { No. }\end{array}$} & \multicolumn{2}{|r|}{1} & \multicolumn{2}{|r|}{2} \\
\hline & ${ }^{13} \mathrm{C}^{\mathrm{a}}$ & ${ }^{1} \mathrm{H}^{\mathrm{b}}$ & ${ }^{13} \mathrm{C}^{\mathrm{a}}$ & ${ }^{1} \mathbf{H}^{\mathrm{b}}$ \\
\hline 1 & $170.50(\mathrm{~s})$ & - & $170.48(\mathrm{~s})$ & - \\
\hline 2 & $44.76(t)$ & $\begin{array}{l}3.03(1 \mathrm{H}, \mathrm{dd}, 3.6,12.6) \\
3.23(1 \mathrm{H}, \mathrm{dd}, 10.0,12.6)\end{array}$ & $44.87(\mathrm{t})$ & $\begin{array}{l}3.04(1 \mathrm{H}, \mathrm{dd}, 3.6,12.4) \\
3.19(1 \mathrm{H}, \mathrm{dd}, 10.0,12.4)\end{array}$ \\
\hline 3 & 79.79 (d) & $4.22(\mathrm{ddd}, 3.6,7.6,10.0)$ & $79.83(\mathrm{~d})$ & $4.22(1 \mathrm{H}, \mathrm{ddd}, 3.6,7.6,10.0)$ \\
\hline 4 & $132.24(\mathrm{~d})$ & $5.86(1 \mathrm{H}, \mathrm{dd}, 7.6,15.6)$ & $131.80(\mathrm{~d})$ & $5.84(1 \mathrm{H}, \mathrm{dd}, 7.6,15.6)$ \\
\hline 5 & $134.35(\mathrm{~d})$ & $6.45(1 \mathrm{H}, \mathrm{m})$ & $134.46(\mathrm{~d})$ & $6.47(1 \mathrm{H}, \mathrm{dd}, 9.5,15.6)$ \\
\hline 6 & $130.13(\mathrm{~d})$ & $6.32(1 \mathrm{H}, \mathrm{m})$ & $129.44(\mathrm{~d})$ & $\sim 6.3(1 \mathrm{H}, \mathrm{m})$ \\
\hline 7 & $134.09(\mathrm{~d})$ & $6.32(1 \mathrm{H}, \mathrm{m})$ & $135.00(d)$ & $\sim 6.3(1 \mathrm{H}, \mathrm{m})$ \\
\hline 8 & $133.55(\mathrm{~d})$ & $6.23(1 \mathrm{H}, \mathrm{m})$ & $132.83(\mathrm{~d})$ & $\sim 6.3(1 \mathrm{H}, \mathrm{m})$ \\
\hline 9 & $130.63(d)$ & $5.80(\mathrm{ddd}, 6.4,8.5,15.0)$ & $132.88(\mathrm{~d})$ & $6.08(1 \mathrm{H}, \mathrm{ddd}, 5.8,8.9,15.0)$ \\
\hline 10 & $33.00(\mathrm{t})$ & $2.41,2.73(2 \mathrm{H}, \mathrm{m})$ & $36.82(t)$ & $\sim 2.4,2.60(2 \mathrm{H}, \mathrm{m})$ \\
\hline 11 & $75.37(d)$ & $5.33(\mathrm{l} H, \mathrm{~m})$ & $70.85(\mathrm{~d})$ & $3.99(1 \mathrm{H}, \mathrm{ddd}, 2.4,5.2,8.0)$ \\
\hline 12 & $39.52(d)$ & $2.36(1 \mathrm{H}, \mathrm{m})$ & $40.16(d)$ & $2.37(1 \mathrm{H}, \mathrm{m})$ \\
\hline 13 & $68.69(\mathrm{~d})$ & $5.11(1 \mathrm{H}, \mathrm{br}, 4.6)$ & 74.37 (d) & $6.47(1 \mathrm{H}, \mathrm{m})$ \\
\hline 14 & $140.03(\mathrm{~s})$ & - & $135.00(\mathrm{~s})$ & - \\
\hline 15 & $125.51(\mathrm{~d})$ & $5.43(1 \mathrm{H}$, br d, 8.5$)$ & 127.48 (d) & $5.46(1 \mathrm{H}, \mathrm{m})$ \\
\hline 16 & $27.04(\mathrm{t})$ & $2.35,2.60(2 \mathrm{H}, \mathrm{m})$ & $26.96(t)$ & $\sim 2.3, \sim 2.7(2 \mathrm{H}, \mathrm{m})$ \\
\hline 17 & $24.12(t)$ & $2.75,2.83(2 \mathrm{H}, \mathrm{m})$ & $23.89(\mathrm{t})$ & $\sim 2.7, \sim 2.8(2 \mathrm{H}, \mathrm{m})$ \\
\hline 18 & $118.48(\mathrm{~s})$ & - & $118.14(s)$ & - \\
\hline 19 & $182.68(\mathrm{~s})$ & - & $182.55(\mathrm{~s})$ & 一 \\
\hline \multirow[t]{2}{*}{20} & $140.23(\mathrm{~s})$ & - & $140.25(\mathrm{~s})$ & - \\
\hline & 一 & $9.64(20-\mathrm{NH}, \mathrm{s})$ & - & $9.58(20-\mathrm{NH}, \mathrm{s})$ \\
\hline 21 & $111.19(\mathrm{~d})$ & $7.80(1 \mathrm{H}, \mathrm{s})$ & $111.19(\mathrm{~d})$ & $7.85(1 \mathrm{H}, \mathrm{s})$ \\
\hline 22 & $185.19(\mathrm{~s})$ & - & $185.32(\mathrm{~s})$ & - \\
\hline 23 & $157.31(\mathrm{~s})$ & - & $157.00(\mathrm{~s})$ & - \\
\hline 24 & $10.63(q)$ & $1.15(3 \mathrm{H}, \mathrm{d}, 7.0)$ & $11.21(\mathrm{q})$ & $1.08(3 \mathrm{H}, \mathrm{d}, 6.8)$ \\
\hline 25 & $20.86(q)$ & $2.09(3 \mathrm{H}$, br s $)$ & $20.85(\mathrm{q})$ & $1.84(3 \mathrm{H}$, br s) \\
\hline 26 & $56.29(\mathrm{q})$ & $3.29(3 \mathrm{H}, \mathrm{s})$ & $56.23(\mathrm{q})$ & $3.28(3 \mathrm{H}, \mathrm{s})$ \\
\hline 27 & $173.18(s)$ & - & $173.31(\mathrm{~s})$ & - \\
\hline \multirow[t]{2}{*}{28} & $49.18(d)$ & $4.70(1 \mathrm{H}$, quintet, 7.0$)$ & $48.97(\mathrm{~d})$ & $4.87(1 \mathrm{H}$, quintet, 7.0$)$ \\
\hline & - & $8.89(28-\mathrm{NH}, \mathrm{d}, 6.6)$ & - & $8.84(28-\mathrm{NH}, \mathrm{d}, 7.0)$ \\
\hline 29 & $17.35(\mathrm{q})$ & $1.44(3 \mathrm{H}, \mathrm{d}, 7.3)$ & $17.64(\mathrm{q})$ & $1.54(3 \mathrm{H}, \mathrm{d}, 7.4)$ \\
\hline 30 & $176.74(\mathrm{~s})$ & 一 & $176.64(\mathrm{~s})$ & - \\
\hline 31 & 44.87 (d) & $2.40(\mathrm{IH}, \mathrm{m})$ & $44.95(\mathrm{~d})$ & $\sim 2.35(1 \mathrm{H}, \mathrm{m})$ \\
\hline 32 & $30.12(t)$ & $\sim 1.6, \sim 1.9(2 \mathrm{H}, \mathrm{m})$ & $30.02(t)$ & $\sim 1.6,1.93(2 \mathrm{H}, \mathrm{m})$ \\
\hline 33 & $25.89(\mathrm{t})$ & $\sim 1.1, \sim 1.6(2 \mathrm{H}, \mathrm{m})$ & $25.96(\mathrm{t})$ & $\sim 1.1, \sim 1.6(2 \mathrm{H}, \mathrm{m})$ \\
\hline 34 & $25.96(\mathrm{t})$ & $\sim 1.1, \sim 1.49(2 \mathrm{H}, \mathrm{m})$ & $26.10(t)$ & $\sim 1.1,1.49(2 \mathrm{H}, \mathrm{m})$ \\
\hline 35 & $26.09(\mathrm{t})$ & $\sim 1.1, \sim 1.6(2 \mathrm{H}, \mathrm{m})$ & $25.94(t)$ & $\sim 1.1, \sim 1.6(2 \mathrm{H}, \mathrm{m})$ \\
\hline 36 & $29.78(t)$ & $\sim 1.6, \sim 1.94(2 \mathrm{H}, \mathrm{m})$ & $29.98(t)$ & $\sim 1.6,1.93(2 \mathrm{H}, \mathrm{m})$ \\
\hline
\end{tabular}

a Measured in pyridine- $d_{5}$ at $125 \mathrm{MHz}$; chemical shifts in ppm from TMS.

b Measured in pyridine- $d_{5}$ at $500 \mathrm{MHz}$; chemical shifts in ppm from TMS.

Although $J$ values of the triene portion in pyridine- $d_{5}$ solution of 1 were not fully obtained, the geometries of the triene portion were determined by the ${ }^{1} \mathrm{H}$ NMR spectral analysis of a 13-monoacetyl derivative of $\mathbf{1}$ in pyridine- $d_{5}$. The observed values of $J_{4,5}, J_{6,7}$ and $J_{8,9}$ in the monoacetate were $15.0 \mathrm{~Hz}, 15.8 \mathrm{~Hz}$ and $15.8 \mathrm{~Hz}$, respectively, indicating the geometries in the triene moiety of 1 are $4 E, 6 E$, and $8 E$. The coupling constants of $6-\mathrm{H}$ in 2 was not completely analyzed on the ${ }^{1} \mathrm{H}$ NMR spectrum in pyridine- $d_{5}$, either. However, the molar absorption coefficient $(\varepsilon)$ values at $260 \mathrm{~nm}, 272 \mathrm{~nm}$ and $280 \mathrm{~nm}$, arising from the triene portion are almost the same as those of $\mathbf{1}$. The geometry of C-6 in $\mathbf{2}$ is therefore estimated to be $E$ as in $\mathbf{1}$. In the ${ }^{1} \mathrm{H}$ NMR spectra of $\mathbf{1}$,
NOE's were observed between $15-\mathrm{H}$ at $\delta_{\mathrm{H}} 5.43$ and $25-\mathrm{H}_{3}$ at $\delta_{\mathrm{H}} 2.09$. NOE's in 2 were also observed between $15-\mathrm{H}$ at $\delta_{\mathrm{H}} 5.46$ and $25-\mathrm{H}_{3}$ at $\delta_{\mathrm{H}} 1.84$. Thus, the geometries of the both double bonds in 1 and 2 are $14 Z$. From the all spectral data, the structures of $\mathbf{1}$ and $\mathbf{2}$ were determined as shown in Fig. 1. The configurations of $\mathrm{C}-3, \mathrm{C}-11, \mathrm{C}-12, \mathrm{C}-13$ and $\mathrm{C}-28$ remain to be determined. ${ }^{4,5)}$

\section{Biological Activity}

Both 1 and 2 were $3 \sim 10$ times more growth-inhibitory in vitro against human cervical cancer cell lines of HeLa, CaSki and SiHa, all of which are HPV gene positive, than against $\mathrm{C} 33 \mathrm{~A}$ and $\mathrm{HT}-3$, both of which are HPV 
Fig. 4. Partial structures of 13,23-diacetyl derivative of $\mathbf{1}$ and 11,23-diacetyl derivative of 2 by ${ }^{1} \mathrm{H}-{ }^{1} \mathrm{H}$ COSY, HMQC and $\mathrm{HMBC}$ experiments (pyridine- $d_{5}$ ).

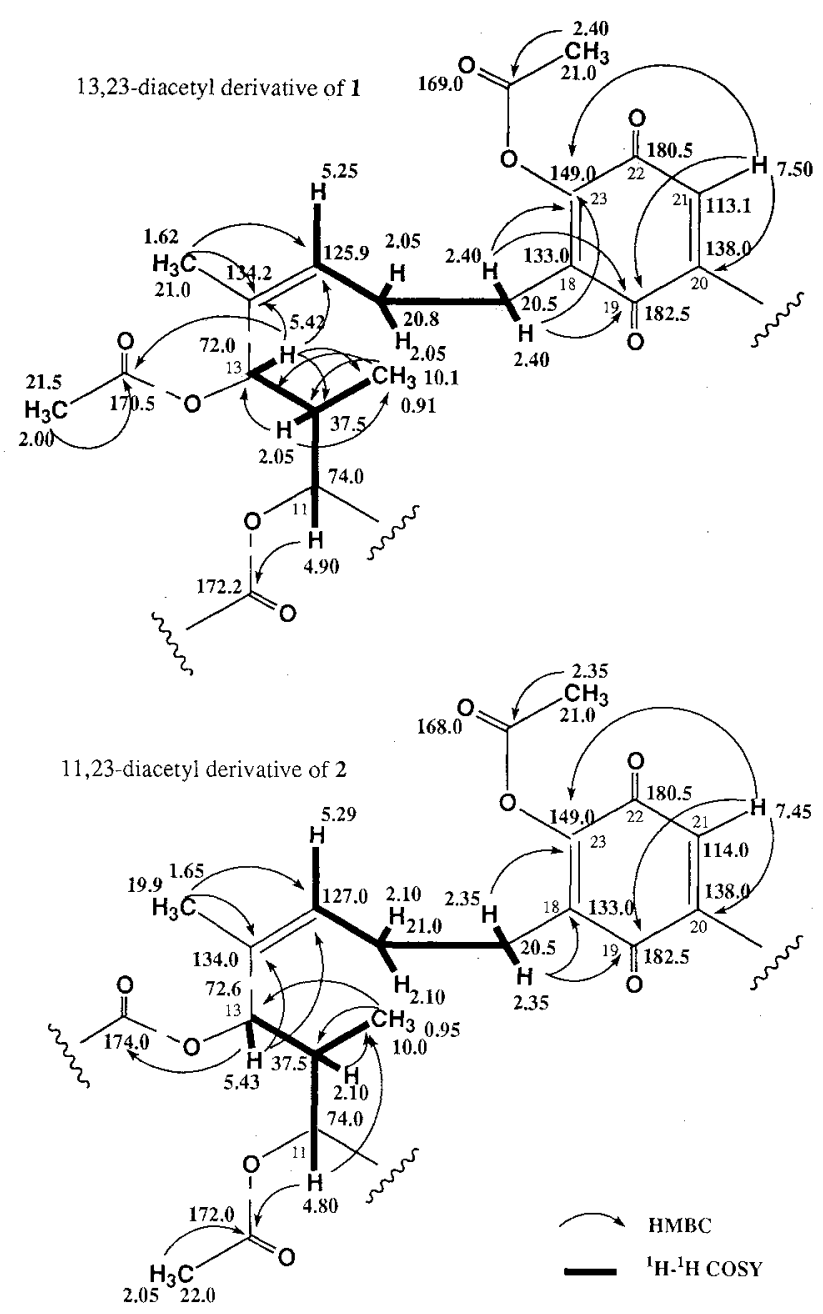

Table 3. Growth-inhibitory activities of 1, 2 and other triene-ansamycins against cervical cancer cell lines.

\begin{tabular}{cllllll}
\hline & \multicolumn{3}{c}{ HPV (+) } & & \multicolumn{2}{c}{ HPV (-) } \\
\cline { 2 - 3 } & SiHa & CaSKi & HeLa & & C33A & HT-3 \\
\hline $\mathbf{1}$ & 0.18 & 0.15 & 0.07 & & 0.9 & 2.0 \\
$\mathbf{2}$ & 0.45 & 0.75 & 0.85 & & 3.5 & 5.0 \\
Mycotrienin I & 0.025 & 0.10 & 0.02 & & 0.005 & 0.03 \\
Mycotrienin II & 0.025 & 0.016 & 0.005 & & 0.008 & 0.01 \\
Trienomycin A & 0.008 & 0.009 & 0.008 & & 0.005 & 0.01 \\
\hline
\end{tabular}

$\mathrm{IC}_{50}: \mu \mathrm{g} / \mathrm{ml}$.

gene negative, as shown in Table 3 . The activity of $\mathbf{1}$ was about 5 times stronger than that of $\mathbf{2}$ when tested. No sign of acute toxicity of 1 was detectable at $100 \mathrm{mg} / \mathrm{kg}$, in mice (ip). 1 did not inhibit the in vitro growth of any bacteria, fungi or yeast at $100 \mu \mathrm{g} / \mathrm{ml}$. As shown in Fig. 5, 1 inhibited the expression of HPV18 E6 and E7 genes
Fig. 5. Effect of 1 on the expression of HPV-18 E6/E7 genes in HeLa cells.

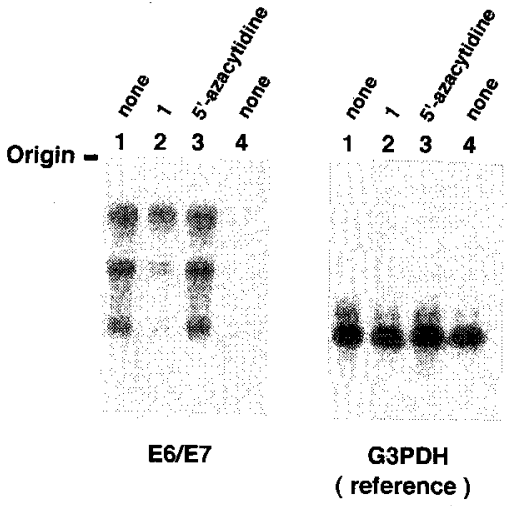

Lanes 1,2 and 3: HeLa cells, Lane 4: C-33A cells.

Lane 1 3: HeLa cells (HPV positive), 4: C33A cells (HPV negative). 1: Control (not treated), 2: Cells were treated with $1 \mu \mathrm{g} / \mathrm{ml}$ of 1 for 24 hours. 3: Cells were treated with $0.04 \mu \mathrm{g} / \mathrm{ml}$ of 5 -azacytidine for 24 hours.

The probes were PCR products by using the genomic DNA from HeLa cells as the template and the following primers; 5-GGCTGCAGAAGGGAGTAACCAA-3 (E6 sense), 5-GGGAATTCAGTTCCGTGCACAG-3 (E6 antisense), 5-GGCTGCAGATGGACCTAAGGCAA-3 (E7 sense) and 5-GGGAATTCCTGCTGGGAT-3 (E7 antisense). A PCR (total volume of $100 \mu \mathrm{l}$ ) was conducted in a buffer (20 mM Tris - $\mathrm{HCl}, \mathrm{pH} 8.3,25 \mathrm{mM} \mathrm{KCl}, 1.5 \mathrm{~mm} \mathrm{MgCl}_{2}$, $0.05 \%$ Tween 20 ) containing 0.5 to $1 \mu \mathrm{g}$ of the template DNA, $20 \mathrm{p}$ moles of each primer, $50 \mu \mathrm{M}$ each of the four deoxynucleoside triphosphates and $2.5 \mathrm{U}$ of AmpliTaqR DNA polymerase (Perkin Elmer, N 801-0060). Thirty successive cycles of denaturation at $93^{\circ} \mathrm{C}$ for $30 \mathrm{~s}$ and annealing/extention at $50^{\circ} \mathrm{C}$ for 1 minute. Human glyceraldehyde-3 phosphate dehydrogenase cDNA (COLONTECH, 9805-1) was used as control for loading. Each probe was labeled by nick-translation (Takara Nick Translation Kit, 6040A).

that had been integrated into the HeLa cell genome (left, lane 3 vs. 4), under conditions where the expression of the control gene was little altered (right, lane 3 vs. 4). 5-Azacytidine, an inhibitor of DNA methylation, showed no or little effect on the expression of etiher the viral genes (left, lane $2 v s .4$ ) or the control gene (right, lane 1 vs. 4), contrary to our expectation. The absence of hybridization with the RNA from C33A (left, lane 1) proved the specificity of our E6 and E7 probes.

\section{Discussion}

1 and $\mathbf{2}$ are rare examples of triene-ansamycins produced by Bacillus strains; so far only aurantinin ${ }^{6)}$ (KM-214) has been known of the Bacillus origin. Under the fermentation conditions employed, $\mathbf{1}$ and $\mathbf{2}$ were obtained as violet powders of iron complexes? ${ }^{7}$, which turned out to be as active as iron-free preparations. The hydroxyl groups in the benzoquinone portions of both 
Table 4. Growth-inhibitory activities of clinically used antitumor drugs against cervical cancer cell lines.

\begin{tabular}{lccccccc}
\hline & \multicolumn{3}{c}{ HPV $(+)$} & & \multicolumn{2}{c}{ HPV (-) } \\
\cline { 2 - 4 } \cline { 7 - 8 } & SiHa & CaSKi & HeLa & & C33A & HT-3 \\
\hline 5FU & 0.4 & 10 & 9.0 & & 0.1 & 0.5 \\
Bleomycin & 3.5 & 5.0 & 10 & & 0.4 & 1.0 \\
Cisplatin & 1.0 & 5.0 & 2.5 & & 0.4 & - \\
Adriamycin & 0.03 & 0.1 & 0.2 & & 0.05 & 0.1 \\
\hline
\end{tabular}

$\mathrm{IC}_{50}: \mu \mathrm{g} / \mathrm{ml}$.

1 and 2 seem to be important for the selective effect against the HPV gene positive cell lines, because mycotrienin-I, which lacked the hydroxyl group, did not show this selectivity. The other ansamycins, for example, thiazinotrienomycins ${ }^{8)}$ showed little selectivity against these cell lines.

Anticancer drugs clinically used against cervical cancers, such as cisplatin, bleomycin, 5-Fu and adriamycin are all more inhibitory against the cell lines that are HPV negative than against those that are HPV positive. This suggests that both $\mathbf{1}$ and $\mathbf{2}$ act somewhat differently from the conventional anticancer agents against cervical cancers. Retinoic acid ${ }^{9)}$ and 5azacitidine $^{10)}$ also showed some selectivity against the HPV positive cell lines, though less significantly (data not shown).

The growth inhibitory activity against HeLa cells of 1 was generally 5 times stronger than that of $\mathbf{2}$, suggesting the importance of the location of the bulky side chain. It is an interesting finding that $\mathbf{1}$ inhibits the expression of the virus-originated gene in HeLa cells, while leaving the expression of acontrol gene almost unaffected. This may explain the selectivity of $\mathbf{1}$ and probably of $\mathbf{2}$ against the cervical cell lines harboring the viral genes; inhibition of the expression of viral genes will lower the intracellular concentrations of their gene products, releasing p53 and $\mathrm{Rb}$ proteins to work as cell growth suppressors. How 1 inhibits the viral genes remains to be studied.

\section{Experimental}

Human Cancer Cell Lines and Culture Conditions HeLa, CaSki (ATCC CRL 1550, cervix), SiHa (ATCC CCL HTB35, cervix), C33A (ATCC HTB31) and HT-3 (ATCC HTB32) cells were grown in EAGLE's MEM (NISSUI Pharmaceutical Co. Ltd.) supplemented with $10 \% \mathrm{v} / \mathrm{v}$ fetal bovine serum (FBS, serum), pH 7.4 (adjusted with $\mathrm{NaHCO}_{3}$ ) at $37^{\circ} \mathrm{C}$, in $5 \% \mathrm{CO}_{2}$-containing humidified air. Cells were seeded at a density of $1 \times 10^{4} \mathrm{cells} / \mathrm{ml} /$ well in Coster 24 -well tissue culture clusters (day 0 ). The cells received test samples on day 1 and were incubated further until day 4. Cell growth was determined using the MTT method and the inhibition caused by the samples was calculated as reported ${ }^{11)}$.
Northern Blot Analysis of HPV18 E6 and E7 Gene Expression

HeLa cells were treated with $1 \mu \mathrm{g} / \mathrm{ml}$ of 1 and $0.04 \mu \mathrm{g} / \mathrm{ml}$ of 5 -azacytidine, which were partially inhibitory concentrations against the cell growth, and RNA was extracted after 24 hours of incubation.

Total RNAs were extracted from the HeLa cells according to the procedure as described ${ }^{12)}$. Ten $\mu \mathrm{g}$ of each RNA sample was separated by electrophoresis in $1.2 \%$ agarose gels containing $2 \%$ formaldehyde and transferred to nitrocellulose filter (Schleicher \& Schuell, BA-S 85 ) by capillary blotting, baked at $80^{\circ} \mathrm{C}$ for 3 hours, and hybridized with ${ }^{32} \mathrm{P}$-labeled $158 \mathrm{bp}$ and 105 bp PCR products specific for HPV18 E6 and E7 genes, respectively (see legend to Fig. 5) under stringent conditions $(50 \%$ formamide, $50 \mathrm{~mm}$ sodium phosphate pH $6.5,5 \times \mathrm{SSC}, 10 \times$ Denhardt solution) at $42^{\circ} \mathrm{C}$ for 15 hours. Human glyceraldehyde 3 phosphate dehydrogenase cDNA (CLONTECH, 9805-1) was used as a control probe for loading. The filters were washed with $2 \times \mathrm{SSC}$ at $65^{\circ} \mathrm{C}$ for 30 minutes and then with $0.2 \times \mathrm{SSC}$ containing $0.1 \% \mathrm{SDS}$ at $65^{\circ} \mathrm{C}$ for 2 hours and were exposed to XRP-5 film (Kodack, 161-8438) with an enhancing screen at $-80^{\circ} \mathrm{C}$ for 3.5 hours.

\section{General}

UV spectra were recorded on a Hitachi U-3210 spectrophotometer and IR spectra on a Hitachi 260-10 spectrophotometer. NMR spectra were recorded on a JEOL JNM-A500 NMR spectrometer at $500 \mathrm{MHz}$ for ${ }^{1} \mathrm{H}$ and at $125 \mathrm{MHz}$ for ${ }^{13} \mathrm{C}$ NMR. Mass spectra were measured on a JEOL JMS-SX 102 mass spectrometer. Optical rotation was measured with a Perkin-Elmer 241 polarimeter.

\section{Analytical Procedures}

An HPLC system (SSC Co. Ltd., 3520) using a $\mu$ Bondasphere $\left(\mathrm{C}_{18}, 5 \mu \mathrm{m}-100 \AA\right)$ column $(3.9 \mathrm{~mm} \times 150$ $\mathrm{mm}$, Waters Co. Ltd.) was developed with $70 \% \mathrm{MeOH} /$ $12 \mathrm{~mm}$ phosphate buffer $(\mathrm{pH} 2.89)$ at a flow rate of $1 \mathrm{ml} / \mathrm{minute}$ at $40^{\circ} \mathrm{C}$, and the eluate was monitored at $260 \mathrm{~nm}$. Silica gel TLC (Kieselgel $60 \mathrm{~F}_{254}$ Art. 5715, Merck) was developed with either $\mathrm{CHCl}_{3}-\mathrm{MeOH}$ $(10: 1)$, toluene-acetone $(3: 2)$, or toluene- $\mathrm{CHCl}_{3}$ $\mathrm{MeOH}(3: 7: 3)$, and spots on the TLC were detected with phosphomolybdate- $\mathrm{H}_{2} \mathrm{SO}_{4}$.

\section{Preparation of 13,23-Diacetyl Derivative of 1}

$1(6.5 \mathrm{mg}, 0.01 \mathrm{mmol})$ was dissolved in pyridine of $0.7 \mathrm{ml}$. The solution was mixed with $0.35 \mathrm{ml}$ of acetic anhydride and stirred at room temperature for 3 hours. Without drying, the solution was subjected to a preparative HPLC. The HPLC conditions were according to the method in the analytical procedure described above. Fractions eluted at a retention time of 30 minutes were combined and dried in vacuo, yielding $4.5 \mathrm{mg}$ of the diacetyl derivative as yellow powders. FAB-MS $m / z 737$ 
$(\mathrm{M}+\mathrm{H})^{+} ;{ }^{1} \mathrm{H}$ NMR $\left(\mathrm{CDCl}_{3}, 500 \mathrm{MHz}\right) \delta_{\mathrm{H}} 2.00(3 \mathrm{H}, \mathrm{s})$, $2.40(3 \mathrm{H}, \mathrm{s})$.

Preparation of 11,23-Diacetyl Derivative of 2

$2(6.5 \mathrm{mg}, 0.01 \mathrm{mmol})$ was dissolved in $0.7 \mathrm{ml}$ of pyridine. The solution was mixed with $0.35 \mathrm{ml}$ of acetic anhydride and stirred at room temperature for 3 hours. Without drying, each solution was subjected to a preparative HPLC. Fractions eluted at the retention time of 40 minutes were combined and dried in vacuo, yielding $3.5 \mathrm{mg}$ yellow powder of the diacetyl derivative. FAB-MS $m / z 737(\mathrm{M}+\mathrm{H})^{+} ;{ }^{1} \mathrm{H}$ NMR $\left(\mathrm{CDCl}_{3}, 500 \mathrm{MHz}\right) ; \delta_{\mathbf{H}} 2.05$ $(3 \mathrm{H}, \mathrm{s}), 2.34(3 \mathrm{H}, \mathrm{s})$.

\section{Preparation of 13-Monoacetyl Derivative of 1}

Acetylation of 1 was performed under the same conditions as the procedure of the 13,23-diacetyl derivative of 1 except for drying the reaction mixture before the preparative HPLC. The monoacetyl derivative was eluted at a retention time of 32 minutes, and finally obtained as yellow powders $(5.8 \mathrm{mg})$. FAB-MS $m / z 695(\mathrm{M}+\mathrm{H})^{+}$; ${ }^{1} \mathrm{H}$ NMR $\left(\mathrm{CDCl}_{3}, 500 \mathrm{MHz}\right) \delta_{\mathrm{H}} 2.14(3 \mathrm{H}, \mathrm{s})$.

\section{References}

1) Howley, P. M.: Role of the human papilloma viruses in human cancer. Cancer Res. 51: 5019 5022s, 1991

2) Sugita, M.; Y. Natori, T. Sasaki, K. Furihata, A. Shimazu, H. SeTo \& N. Otake: Studies on mycotrienin antibiotics, a novel class of ansamycins I. Taxonomy, fermentation, isolation and properties of mycotrienins I and II. J. Antibiotics 35: 1460 1479, 1982

3) Lazar, G.; H. Zaher, M. DamberG \& A. Zeeck: Ansatrienin A2 and A3: minor component of the ansamycin complex produced by Streptomyces collinus.
J. Antibiotics 36: 187 189, 1982

4) Smith, Amos B., III.; John L. Wood, Weichyun Wong, Alexandra, E. Gould \& Carmelo J. Rizzo: (+)Trienomycins A, B, and C: Relative and absolute stereochemistry. J. Am. Chem. Soc. 112: 7425 7426, 1990

5) Smith, Amos B., III.; Joseph Barbosa, Weichyun Wong \& JoHN L. WOOD: Total synthesis of (+)-trienomycins A and F. J. Am. Chem. Soc. 117: 10777 10778, 1995

6) Nishikiori, T.; R. Masuma, R. Oiwa, M. Katagiri, J. AWAYA, Y. IWAI \& S. ÖmURA: Aurantinin, a new antibiotic of bacterial origin. J. Antibiotics 31: $525 \sim 532$, 1978

7) Anslow, W. K. \& H. Raistrick: XCI. Studies in the biochemistry of micro-organisms. Biochem. J. 32: 687 696, 1938 .

8) Hosokawa, N.; H. Naganawa, H. Innuma, M. Hamada, T. TAKeUCHI, T. KANBE \& M. HoRI: Thiazinotrienomycins, new ansamycin group antibiotics. J. Antibiotics 48: $471 \sim 478,1995$

9) Pirisi, L.; A. Batova, G. R. Jenkins, J. R. Hodam \& K. E. CREEK: Increased sensitivity of human keratinocytes immortalized by human papillomavirus type 16 DNA to growth control by retinoids. Cancer Res. 52: 187 193, 1992

10) Roesel, F.; M. Duerst \& H. zur Hausen: Selective suppression of human papillomavirus transcription in non-tumorigenic cells by 5-azacytidine. The EMBO J. 7: $1321 \sim 1328,1988$

11) Tuchiya, K. S.; T. Kanbe, M. Hori, Y. Uehara, Y. Takahashi \& T. TAKeuchi: Distinct effects of clinically used anthracycline antibiotics on ras oncogene-expressed cells. Biol. Pharm. Bull. 16: 908 911, 1993

12) Favaloro, J.; R. Treisman \& R. Kamen: Transcription maps of polyoma virus-specific RNA: Analysis by twodimentional nuclease $\mathrm{S} 1$ gel mapping. Methods Enzymol. 65: $718 \sim 749,1980$ 